\title{
Theistic Panpsychic Communicative Rationality
}

\author{
Maduabuchi Dukor \\ Nnamdi Azikiwe University, Awla, Nigeria. \\ Email: madudukor@yahoo.com
Received August $11^{\text {th }}$, 2011; revised September $16^{\text {th }}$, 2011; accepted September $24^{\text {th }}, 2011$.
}

\begin{abstract}
The difference between a scientific system and the non scientific system is only a matter of forms of rationality: so also the difference between empirical system and non empirical system explainable in terms of the kinds of rationality systems in their structures. Similarly, the classification of civilized cultures and primitive cultures or the black civilization and western civilization is all about forms of rationalizations. That is because the form of explanation of European Society is different from the form of explanation of the Black African animistic society. However, structural functionalism is an attempt on a large scale to combine the methods of both functionalism and structuralism which is not only extant in African philosophy but also embedded in the practice of tradition. Indeed Theistic Panpsychic rationality is culturally structural and functional thereby qualifying to be described as structural functional Panpsychic communicative animism.
\end{abstract}

Keywords: Theistic, Panpsychism, Animism, Communication, Rationality, Oralism and Proverb

\section{Introduction}

The traditions of Kant, Hegel, Schelling, Marx etc are forms of rational enquiries into particular socio political formations of their respective cultures. The American pragmatic thinkers like Pierce, Meed and Dewey had the vision and understanding of radical participatory democracy. Horkhemer, Adorno, Marcus and other members of the Frankfurt school formed a rational system antithetical to the methodology of modernity and the Enlightenment Europe. The history of Western philosophy is indeed the history of rational explanations and communications. Yet in the ancient Africa (uninfluenced by western tradition) there is a peculiar and unique form of rationalization process in form of oral tradition that is animistic but symbolically and philosophically described as theistic panpsychic communicative rationality and its antithesis theistic panpsychic literally criticism.

Until the emergence of the critical theory, it was not obvious that the soul of humanity was being desecrated by modernity. Consequently recreating the world from the battered assault of modernity becomes the preoccupation of Habermas and the Frankfurt school even as the pristine African consciousness holds tenaciously the lubrics of the universe which the former failed to recapture. African society is a fallibillistic critical comnity whose perception and utilization of society is partly a function of transendentalism and inter-subjectivism, yet based on Theistic Humanism. However, Habermas sought the Kernel of what he was to later call "Communicative action". For him:

Communicative action is a distinctive type of social interaction the type of action oriented to mutual understanding. It must be distinguished from other types of social action and non social action which are oriented to success, to the efficient achievement of ends. These later action types exhibit the form of purposive rational action where we seek to achieve an end or goal by appropriate means (Beinstein, 1983).

However, communicative action which is in form of proverbs and prayers or liturgies which in African philosophy is based on Theistic Psychic rationality is a kind of purposive rational actions purposive rational actions, according to Наbermas, can be treated under two different aspects, the empiri- cal, efficiency of technical means and the consistency of choice between subtle means. The rationality of means requires technically utilized, empirical knowledge. The rationality of decisions and goals requires the application and inner consistency, of value systems and decision maxims, as well as the correct derivation of acts of choice. Theistic Panpsychic rationality not only emphasizes decisions that requires the understanding and consistency of value systems and decision maxims, as well as the correct derivation of acts of choice but also the rationalizastion of empirical knowledge as a secondary quality in African philosophy Rational purposive actions which is the inner consistency of value systems and decisions maxims have transcendental claims and justifications and the rationality is what I call Theistic Panpsychism which ethno methodologically and unscientifically is an animistic thought process and actions. Animistic philosophy is a pervading and immanent philosophy that underlay socio-political and techno-empirical actions in Black man's universe. The ultimate justification or foundationality which is Theistic Panpsychism and Theistic humanism theoretically manifest in a host of symbolic interactions, arts, aesthetic monological regularities and empirical analytic hermeneutics in all spheres including the esthetics, the cultural, the political and the technical. Unlike the theistic panpsychic philosophy, modernity disintegrated objective reason into partial moments, scientific-technical rationality, practical moral rationality, and aesthetic rationality. Like Adomo, a post-odernist, African philosophy of Theistic panpsychism rationalizes aesthetic production so as to achieve a sublation of instrumental rationality into a non repressive form of reason. African philosophy with its metaphysical rationality rescues the arts, painting, dancing etc. from the metaphysical and aesthetic hiccups of instrumental rationality and provides a framework of theistic panpsychic rationality for instrumental reason to be sublated into a field of forces which is ruled by logic higher than that of identifying instrumental action. Through the metaphysical foundation of Theistic Panpsychism, African philosophy distills out a non repressive instrumental rationality and achieves an aesthetic unity out of a manifold of its individual elements. Authentic work of art in African philosophy supported by the metaphysical foundation of Theistic Panpsychic rationality exhibits 
a resemblance of reconciliation and achieves a non repressive form of social and spiritual integration.

\section{Arts as Communicative Action}

Generally, when we think of art, what might first come to mind is "beauty", "intrigue”, "imitation”, "festivity”, and so on. Plato's states that "art is the imitation of sensible things by means of a copy at lower level of reality" (Martin and Jacobus, 1983). Here, imitation is used to suggest a similarity in appearance between art and object of the material world. On the other hand, material objects are perceptible to our sense, thus we are aware and certain of them. In other words, artist actually endeavors to imitate all that is visible, and in essence, immaterial objects of our sense. This is contrary to Plato's notion, which is embodied with elements of idealism, which is that the artist imitates sensible thing, which are but faint shadows of reality. The social, spiritual, artistic or aesthetic integration in Igbo African philosophy, independent of instrumental reason, is nomological, theistic panpsychically communicative, interactive and idealistic. Art, in this sense, endeavors to depict the features, qualities, facts, and character of the original. In this sense, art can never be the genuine but a copy or specimen, which is made to look like the original. Thus, Aristotle rightly states, that it is "natural for man to delight in works of imitation" (Aristotle). For communicative actions reasons, "delight”, "beauty”, or "pleasure" is paramount to artistic representations. This view may have been initiated by Santayan's notion which states that beauty, which can only be found in the sensory appearance of things, is pleasure objectified. Implicitly, pleasure is actually cast as a quality of the object resulting from natural impulse, which appear to us as beautiful. Santayana, argues that, "The beautiful is itself an essence, an indefinable quality felt in many things, which however disparate they may be, otherwise receive this name by virtue of a special emotion, half wonder, half love, which is felt in their presence" (Urmson,1984). In aesthetic communicative interactions and actions the beauty of something which one sees or hears lies in one's whole attention centering on loving care and on the precise character of that with which one is confronted. In doing this, one is really not concerned with the irrelevant factual context in which this thing is embedded. What is found to be beautiful then is a given essence, not the physical things. Basically, the essence attracts and holds the interest of the viewer when it is beautiful and charming. Typically, this leads one into aesthetic contemplation. Further, art gives a unique quality of pleasure, which appears distinct from the pleasure derived from the satisfaction of any of the instincts. Such a pleasure can be derived only from art, which is pure and worthy in itself. This is typically hedonistic, in view of the fact that beauty lies in the ability of an object to please, when in aesthetic contemplation.

In addition, both the expression of art and the contemplation of beauty are activities of the self. Art can be interpreted as a free expression. Generally, art portrays freedom, frankness 'and independence, especially, of the artist. In light of this, 'artist' may suggest an individual, who can flourish only by becoming free of all collective entanglements and commitments in the external world; just like the spectator is entranced by the beauty of artworks. Similarly, the artist is entranced by the beauty of material object; he dissociates himself from elements of his immediate surroundings but surrenders himself to the trance of tranquil state of aesthetics. In other words, the artist endeavors to acquire full mental and steady concentration on the object of aesthetics which in turn, enables him to express himself fully in his art, otherwise his art does not assume art of the highest standard. In fact, such an art will be no more than a mere imitation of nature, or an expression of the tastes of the public whom it may aspire to please (Adorn, 1984). Art is organizes and endeavors to be orderly, like it is in nature. Also, art is brought into being not only by its physical appearance or the material component, but most importantly, by the beauty it embodies. In fact, it will be consistent to state that since art is an imitation of the material world, then beauty may well be an extension of the beauty embodied in all original and natural materials, objects, and events such as stones, water, colours, animal, wood, vegetation, language, sound, movement, and so on. In other words, beauty is a nature given essence embedded in all that is nature-created. All art forms come to being as a result of nature given aids. For instances, dancing involved the human body and movements. Music is complimentary to dance; it involved human body (as in gesticulation), language, and action.

African art is a genuine indigenous art, which is not influenced by foreign ideas and culture. It is an art, in its pure Theistic Panpsychic animism. However, according to Osa D. Egonwa, "African art could be defined as the Creative objectifycation of Africans, which bear the imprints of African aesthetics in their styles and subjective contents”(Egonwa, 1994). African aesthetics is technically displayed on the African artwork, verbalized by the African in the evaluation of objects of aesthetic and communicative experience, and is rooted in the collective views of the people.

The African believes the inanimate but animistic objects have essence, which is spiritual. Only this 'life force' makes some of these objects suitable for certain functions, determines their physical qualities, accounts for the choice of materials such as gold, bronze, brass, wood or clay for artistic creations and the high panpsychic and animistic symbolisms and metaphors. For instance, among the Yoruba, a four-sided shape refers to the four powerful deities: East represents Sango, West represents Ifa, and North represents Oduduwa and the south represents, perhaps, the sumpem deity God Otadumer/Oloriun. A sense of uniqueness and style is revealed in traditional African painting. The first style used was the application of carefully outlined dark shadows to capture descriptive scenes of animals and human in motion. This style of silhouette isn't only beautiful and elegant, but it is also original to the African. Also, there were the realistic representation of figures, and polychrome tendency. In fact, in the attempt to capture realistic images, natural colours, such as copper, red, brown, orche, and Kaolin white where obtained from minerals such as iron, hematite, chrome and lime among others and bound with a variety of adhesive agents were used. Painting and drawing were used for decorative, magical and preservative purposes. In fact, in ancient Egypt, the belief in after death gave rise to realistic emphasis on painting and drawings of kings and nobles, used to ensure that they continue to enjoy all that they had on earth even after death (Egonwa). These kind of animistic Panpsychic sculptures serve as aesthetic communications. The richness of the facial expressions in some of the stone sculptures suggests that they may have been idealized portraits of people. Also, there are evocative stone monoliths with engravings metal work with ritual symbols, stool, staff's office, some form of animal and human figures. The blacksmiths were talented and well skilled as they produced exclusive aesthetic communicative designed works, especially for religious purposes and for the royal class. African wood sculpture is predominantly naturalistic representations of human figures usually in African regalia, 
especially if the figure depicts a chief, animal figures or decorative motifs. African objects of art, especially the wood sculpture, are meant to be perceived, appreciated and relished, but except in cases when members of secret cults or groups used them. However, the African sculpture is simply a folk expression of folk-people as diverse as the traditions of Africa. The intricate designs, which are some of major characteristic of African sculpture suggest the great talents, dexterity and craftanship in traditional society.

Africa also produced dancers' musicians and poets. In traditional society, every event such as war, marriage, birth, death, ritual, initiations, and festivals is celebrated in public sphere accompanied with songs and music. Music is a means of theistic humanistic communication. In its rhythm, melody and harmony music is blend in such a way as to evoke theism, animism, emotion and ecstasy. There are many musical instruments particularly drums of different kinds; it is this that gives our dances a communicative animistic spirit and variety. The emotional responses to the inspirational quality of the theme, vocals, the power of its story and the vividness of its characterizations are the communicative actions of African music and poetry. Poetry is recited or sung orally. Studies of the traditional literature of many societies such as Igbo, Swahili, Yoruba, Uganda and Kenya, have shown that African communities have always had their own ideals of the nature and function of poetry. Traditional poems are a serious art and communicative action for dealing in a wide range of human experiences in rich figurative languages, presenting beautiful pictures in words and certain deep reflections about the world and man's place in it, and treat the relation between man, his environment and nature, all of which are theistic Panpsychic animistic in nature. Traditional oral poetry is composed as religious songs, and lyrics, dirges, praise-poetry, prayers, proverbs, myths, and so on. Also, the emotional facial expression by poets and dancers enhances the aesthetics and beauty of traditional songs and poetry.

Also, beauty, sensuality, artistic sensitivity, and a taste for spectacle suggest already existing aesthetic culture in Africa. For instance, in the West African sub-region, the clothing of both genders is almost the same. Generally, it ordinarily consists of a long piece of cloth wrapped loosely around the body. However, the lengthy job of adding finishing touches to pieces of clothing with an aesthetic arrangement of multi-colour paintings, dyes, embroidery and breads are delicately and artistically done, especially for ceremonies, festivals or for royalty.

\section{Theistic Panpsychic Animistic Arts and Literally Criticism}

Theistic Panpsychic rationality as the underlying principle of African philosophy points to some element of the universal in the communicative epistemic actions of African art. This presupposes a position that refuses to create mutual exclusiveness between western and African aesthetics except the difference in the underlying cultural principles that separately informed both. African arts and aesthetic as modes of communicative rationality have sacred and ritualistic superstructure, the reason for which I have described theistic Panpsychism as a mode of rationality. This Panpsychic and animistic nature of African art and aesthetic sensibility gives it uniqueness, yet as an art and aesthetics in continuum with civilization of humanity. It is neither Platonic nor Kantian in methodology but the same as a mode of intellectual appreciation of nature. Hence Eugenia collier critical theory that treats African art and aesthetics and western version as mutually exclusive is a deservice to artistic and aesthetic humanity. The background to this position is the truncated invention and methodology of J. O. Ojo:

I have indicated earlier that European artists recognized African sculpture as an art form. This is rather a pity because many of the objects which European artists regard as works of arts were not conserved as such by their creators. Many of these objects, which Euro-American aesthetic sensibility classified as works of art are in fact sacred and ritual objects, objects whose forms are dictated partly by tribal convention, technical instruments each of which has its own well defined functions. But the religious and spiritual backgrounds which brought them into being are not often considered. It is not realized by many that art in the phrase "African Art" is an unsatisfactory term and that when used, aesthetic analysis based on either Platonic or Kantian definition of beauty is unapplicable (Collier, 1986).

Art as an intellectual appreciation of object and as a means of social and cultural communication is a universal value. But aesthetic valuations differ from one race to another and that of the African is sacred and ritualistic. The meanings attached to art by the Africans may be different from the meanings attached to it by the Europeans. However Collier rightly stated that "African art grows out of a concept of the universe which holds that man and nature are one: that the spirit world and physical world are equal realistics; the past, present and future exist together and that man is in harmony with his world. This is a monistic or naturalistic conception of art that explains African cosmology; there are, however, other conceptions that caters for other segemental realities without a total bifurcation of the ultimate principle that underlie everything that bespeaks of Theistic humanism or Theistic panpsychism in Africa. Though God created man to have dominion over nature, the African maintained dominion at animistic and ritualistic level conditioned with theistic panpsychism: while the western dominion of nature takes on a scientific and technological dimension that subsists outside the confines of nature and spirit and the turns against it. Western metaphysical and social dualism presupposes a human that emphasizes the person as an individual.

Western humanism claims a schism between man and nature. The central assumption of this humanism is "a dualism of man and nature, as opposed to the monism assumed by naturism”. On the other hand, African unity of man and nature and its dualism of soul and spirit underlies a special form of humanism that is obedient to (and not against) nature, a humanism that is derived from the gods and God, a humanism that artistically and aesthetically amenable to the objects of nature in the name of Theistic humanism and panpsychism. It is therefore false for Collier to assert that "humanism is the antithesis of the unified view of Africans" (Collier). This is because the western form of humanism is different from the African humanism. While the western humanism is scientific and technological the African humanism is metaphysically theistic humanism, an amalgam of the spiritual transcendental and regrettably crudely inchoate scientific animism that subsists at the level of subliminal existentialism. The western aesthetic humanism operates with an instrumental rationality that pits man against nature, an offspring of the hollowness and destructive ontology of the modernity, while Africa aesthetic humanism is coherent specie of the holistic, communal, social and monistic world view superimposed in the ultimate universal principle of theistic panpsychic superstructure of transcendental unity of apperception in African philosophy.

Rational aesthetic communication in African philosophy activates the sensibilities that produce sculptors, proverbs myths, 
tales, songs poems dance, tragedy etc. that relates man to subterranean objects and entities that pronounce the dependence and mortality of man and his limitations in the face of the infinite and immortal creator perceived as synonymous to nature. In this sense, the African art or aesthetics is a deeper reality than the Western understanding of art, though the difference borders at the level of culture, the former is Theistic humanistic and panpsychic while the other is scientific and technological. Eugenia Collier captures the substance of African culture as follows "Art is like a pebble dropped in water... individual, family, community, universe, spirits world, all brought into meaningful relationship through art. Thus art is functional and highly disciplined, serving purposes that are social, political and psychological” (Collier). In African philosophy art is participatory being rational instrument of communication and dynamic, realistic and concrete means of realizing the society's moral, social, spiritual and economic goals. As a moral vehicle, "it is committed to truth and ultimately to the sacredness of the human spirit" (Collier). There is the element of Puritan view of art in African philosophy as much as in Plato's conception of Art. Plato's view of art as much as that of the African is both relevant to the political welfare of the state and the religious or spiritual salvation of the individual soul. For Plato, "lyric poetry is an utterance of the gods through the medium of the poet conveyed through virtual "possession" (Collier). This view by definition has moral and African theistic animistic implication. Hence African art and Plato's art coincide in their spiritual, political and moral interests in the society.

African aesthetic communicative rationality presupposes African forms of political organization and government as well as the totality of individuals' cultural and behaviouralistic manifestations and as directed by Theistic humanistic and panpsychic tendencies. In the art there are both Egoistic and altruistic conceptions and in some cases outright conceptions of pleasure. In African artistic and aesthetic conceptions there are material and emotional elements as shown in a carved figures which contained the spirit of an ancestor, a praise song to a chieftain, in a dance to thank the gods for a beautiful harvest etc. I agree with Prozirimu that African art is different from the art of the whites,

The authentic critical standards must be born from the works of specific societies and their representative creators. That is where it all begins, criticism. Not in Aristotle's Poetics. The Poetics were written from Greek dramatic performances and experience, it was a distillation and a summation of what appeared to be operating principles from observed plays. Our plague has been to think that Greece was the universe and Aristotle the world oracle (Collier).

In terms of literally criticism, writers must not study African arts and aesthetics from the mind set of white standard but from the fundamentally metaphysical theistic principles that form the superstructure of blacks' world view, as "black aesthetics is an outcome of black societies" (Collier). African art is a Theistic panpsychic art that reflects the values of communalism and community, and communicatively and rationally functions as a means of sustaining the society or the community in aesthetic and public spheres. African aesthetics and arts is also mythical and could be analyzed and understood at metaphysical level because of the people's collective unconscious based on the supra-natural Theistic panpsychism. The nature of African may agree to some extent arts therefore, has what one can call communal archetypes and myths reinforcing the entire world view. African literature, aesthetics and poetry is fundamentally couched in mythical planks underlying the mysterious and su- pernatural nature of the universe, and its creator, for which in many ways it differs from Freudian and Marxist analysis of arts. African poetry is, in the same sense, in search of the ultimate in the mythical universe; it is both an expression of ultimate reality and the emotional phenomenal nature. The African would agree with T.S Eliot that "Poetry is not a turning losses of emotion, but an escape from emotion: it is not the expression of personality" (Collier). African aesthetic experience is a response of sensitivities to the supernatural and the natural, the Theistic humanistic structure of the universe, created, static or dynamic, but which represent or articulate essential archetypes, symbols and attitudes of the community and uncreated.

\section{Orality and Forms of Communication}

Oral tradition is one of the theistic animistic elements of African folk literature which serves as vehicle for historiography, and communicative actions consist of folk takes, ballads songs, epic narratives, myths and legends, riddles, proverbs, recitations and chants, orations festivals, drama and ritual performance A tradition is oral if it has no written literature or sacred scriptures. The Webster's Third New International Dictionary defines oral tradition variously as follows:

The process of handing down information, opinions, belief and customs by word of mouth or example, transmission of knowledge and institution through successive generations without written instruction. Cultural continuity embodied in a massive complex of evolving social attitudes, beliefs, conventions and institution rooted in the experiences of the past and exerting a normative influence on the present. Something existing only in popular belief inherited reputation or memory (Webster, 1971).

In order for a thing to be regarded as traditional, it must be widely understood and practiced in a society and it must have been handed down for at least a few generations. Unfortunately, the term is misapplied to represent just anything anyone wishes to give legitimacy. Strictly speaking however, oral traditions are those recollections of the past that are commonly or universally known in a given culture. Versions that are not widely known should be dubbed testimony while those that relate to recent event belong to the realm of oral history (Henigo, 1982). As a coherent communicative network of theistic animism oral tradition consists of myths, legends, stories, proverbs, belief, folktales, songs and dances, liturgies and rituals, pithy sayings, riddles and adages, social attitudes, conventions, institutions and customs. Some of these communicative symbols and actions appear in work of arts and crafts, symbols and emblems, names of people and places, shrines and sacred places. Works of art are not merely for decoration. They usually convey religious feeling, sentiments, aesthetic feelings ideas and truth (Ajayi, 1981). Oral tradition involves the handing down of a thought system from one generation to another by word of mouth or by practice. The elderly and the wise-men are regarded as the purveyor of the thought system. Oral traditions can be described as testimonies of the past which are deliberately transmitted from mouth to mouth. These traditions are neither rumours nor sensational stories but eyewitness accounts that have been passed from generation to generation. The absence of the art of writing in traditional African societies has made it necessary to employ oral traditions as a means of preserving and transmitting African religious beliefs and practiced. These oral traditions constitute the scripture of African traditional region. They are mirror through which the religion of 
African is known (Aderibigbe, 1987). However, the reliability of the various form of oral traditions as vehicle for the authentic beliefs of the people varied. For example the condensed, and memorized forms like proverbs, names and pithy sayings, which are said to be memorized as they were handed down from the time immemorial, are certainly more reliable than myths, legends, folktales and daily speeches which are susceptible to changes and sometimes have distorted version. Oral tradition is both an art and an instrument of communicative action in African philosophy with its epistemological foundation in the unity of apperception consciousness or Theistic Panpsychism. No human face is exactly the same as another human face, but it is like many others in having two eyes, a nose, two lips and two ears. In the same way, no two people even respond to God's presence in exactly the same way.

Similarly each particular religion has a particular character because of the particular people who practice it. For example, Islam grew in the Caravan Cities of Arabia, Hindus developedin India and African religion in the indigenous religion of the Africans. It is the religion that has been handed down from generation to generation by the fore-bears. It would be seen, therefore, that in one form or the other every person in the world over seems to have in him a force that links him with the "Ultimate reality" called God (Aderibigbe).

The force in African philosophy is Theistic Humanistic Panpsychic animism. It should be noted that the absence of sacred literature and also the absence of imposing sacred buildings like mosques, churches, cathedrals and temples should not be interpreted to mean that African religion cannot be known. The history of religions the world over testifies to the fact that the societies from which these religions emanated were backward and pre-literate and the revelation given to them existed in oral form before being committed to writing at a much later date In the same way, Africa religious ideas or Theistic Pan- psychic animism exist largely in oral form. Thus, inspite of the fact that Africans have no written records, their religious beliefs and practices can be known and revealed.

African Panpsychic animistic philosophy is mirrored through some institutionalized devices. Some of these devices are both oral and non-oral. The oral devices include myths, proverbs, theophorous names, everyday speech, pithy saying, liturgy and songs. The value of proverbs as a reservoir for religious beliefs and customs of non-literate people derives from reportorial communicative value of proverbs in most African Societies. These proverbs reveal a lot about African philosophical belief, especially ideas about Theistic Panpsychism. From some of these proverbs, we learn of the following attributes of God: Creator, omnipotent, holy, compassionate, omnipresent, selfexisting, accessible and determiner of destiny. Some of the proverbs also describe his power, his transcendence, his mercy, his care for his creature, his lordship over the universe and his divine providence. Proverbs are natural to the people. They are the rational voice of the people in the profound sense and are accepted as a true index of what a people regard as true and are interpretative of the principle of life and conduct. Among Africans, the use of proverbs is cultivated as an art and cherished as an instrument of rational communication. The Yoruba say that proverbs are horses for retrieving missing words. The Zulu also assert that "without proverbs, language would be but a skeleton without flesh and to a body without soul" (Aderibigbe). The Igbo have it that "a child who knows how to use proverbs has justified the dowry paid on his mother's head". The same could be said of most African peoples.
Most of these proverbs refer to Theistic humanism as the spiritual, physical and moral principles of African philosophy. For instance the power and reliability of God are expressed by some African proverbs. The Bangerwanda (Rwanda) say "The tree set up by manna (God) cannot be blown down by the wind" (Jacobs, 1997). Similarly the omnipresent of God is expressed by this Akan Proverb: "If you want to tell God, tell it to the windOral traditions have played important roles in revealing both the ethical as well as the communicative rationality of the Africans. They serve moral purposes. Some of these oral traditions e.g. proverbs reveal the value judgment and morality of the people. Good character is cherished in such a way that everyone is expected to cultivate it. According to the elders, good character is the king of medicine for fortune. Proverbs project the belief that the entire world is a stage, as we have our entry and exit. Consequently, life itself is transitory and ephemeral. Hence the slogan "As I watch through this span of life, what name, what image do I have behind, what hope and what thought for the future, preoccupies their minds" (Jacob). Therefore, according to the African, man should do good and hate evil. Thus, for the Igbo good character is the key to success and that good name is better than riches. The Yorubas believe that character is a god, it supports one according to manners and the way he behaves. Consequently, "Whatever one sows he shall reap" (Jacob). Hence, the watch-word is that good character is the adornment of man.

They also stress the fact that worthless people are so many as the grass while good people are dearer than the eyes. From the foregoing, one cannot but agree with the view that proverbs as oral tradition are used to emphasize the importance of good character among the Igbos and Yorubas. The following could be considered as among the proverbs which deal with the moral value of the Yorubas. For instance, when the earth worm pays respect to the soil, the soil opens for it (Delano, 1972). The proverb serves as an advice to the experienced people that if they accept their position and give honor to those who are superior to them, they will receive favour and help they need. With this proverb, it is necessary to state here that the African greatly believe in the saying that if youths could give respect to the elders and listen to the advice and the dictate of the elders, they believe that their ways will be straight in life. There are some proverbs which serve as warning to our future living. For instance, if a kinsman is not warned in time when he eats poisoned insect, the resulting itch will keep the whole family awake (Delano). The proverb is pointing to us that the actions of those near to us may affect our ways of life and so it is wise to warn them if they are acting imprudently so as not to suffer with them in the very near future.

It is however pertinent to mention here that through oral traditions, the Africans uphold dearly the spirit of unity and togetherness which is not fundamental but also instrumental in living a progressive and peaceful life. This conception is well conceived in proverbs. Consequently, the proverbs such as "the decease which troubles forty also torments three hundred and when the right hand washes the left and the left washes the right, makes both hands clean, do not only encourage the spirit of unity and togetherness but also stress its importance (Odujinrin, 1984). This gives incentives to mutual help which is beneficial to all parties concerned for instance. "The child's hand cannot reach the shelf, the elder's hand cannot enter the gourd”. Oral tradition through proverbs recommends cooperation between the young and the old. It points out that the old need the young and the young need the old conversely. It could be used as a rational communicative instrument whenever there is a quarrel 
between young and old people.

Proverbs are wise sayings; simply expressed they are the words of elders, which are words of wisdom. A wise man has it and get wiser, while a foolish man hears it and becomes more foolish. The ideas expressed in proverbs are generally regarded as truisms truths, which cannot be rationally disputed because they express certain truths about value and reality. The elders say proverbs are the horses of speech, if communication is lost; we use proverbs to retrieve it. Generally, proverbs are employed by elders in a discussion of importance. The more an elder can appropriately use proverbs, the more he is regarded as a man of wisdom. Like a proverb: "The drum sounding a message of war is beaten in critical manner, only wise men can dance to it, and only experience men can understand it" (Ajibola). The value of proverbs lies in what it reveals of the thoughts of the past, expressed of the present and speculated on the future as well as on the facts of being a model of compressed and forceful language. Apart from drawing on it for its words of wisdom, the speaker or user of proverbs takes interest in its verbal technique, its selection of words, and its use of comparison as a method of rational communication.

However, proverbs are not only a body of shorts statements and insight of a community into problem of life, but also a technique of verbal expresses. It is a traditional saying which expressed the basic common truth of a people. According to Oladele Taiwo, oral traditions deal with all aspects of life. They are used to emphasize the words of the wise and the stock-in trade of old people, who use them to, convey precisely moral lessons, advice warnings, since they make a greater impact on the mind than ordinary words. The judicious use of proverbs is usually regarded as a sign of wit (Taiwo, 1967). Proverbs as oral tradition form the main structural materials of the language of communication. Appropriate and correct usage of proverbs is important among the users. Oral tradition through proverbs is constantly pressed into the service of the elders during deliberations in council and at home when settling disputes. It is generally believed that a relevant proverb if mentioned throws light on the subject and drives points so vividly home that the impact enters very fully into their feelings. Consequently, one can be allowed to take part in communal discussions if he is considered to be versed in the use of proverbs.

\section{Epistemology of Proverbs}

A general epistemological survey of some African proverbs will attempt one to conclude that the Africans are also empiricists. Knowledge to them is some times based on experience. Elders say "experience is the content of wisdom", we do not stay away and claim to know what a particular soup tasted like and news is not as reliable as personal witnessing. In other words, proverbs readily reflect the epistemological and panpsychic animistic proposition that knowledge is derived through experience. Under this situation, if something bad happens to someone, for instance, if one looses a job, the fact that one has personally experienced that danger of unemployment makes him to know the evil effect of unemployment in the society.

The African also through proverbs express the view that knowledge is a universal phenomena, hence the proverb 'wisdom is not an exclusive possession of any one and does not belong to any individual'. This proverb is similar to Yoruba proverb; "the young man is wise and an elderly man is also wise as a result of which Ile-Ife was founded" (Kola, 1982). This proverb concerns Ile-Ife which is regarded as the cradle of Yoruba land. The proverb arose from the story of Oduduwa who was the founder of Ile-Ife. He was a warrior who was said to have traveled all the way from a place around the present day Mecca. He eventually got a piece of vast and plain land where a young man suggested to him that they should settle and which he readily accepted. Hence, they settled down and agreed to call the place Ile-Ife, which simply means a plain land or an expanded of land. The proverb is epistemological and rationally communicative in the sense that knowledge is not restricted to the elders alone; although an elder could be more knowledgeable, knowledge is also extended to the youth. In African tradition, it is believed that the elders are wise but at the same time, the elders could sometimes tap from knowledge of the youth.

A proverb says: "The people of our compound are not helpful, our relatives have no character but we cannot compare them to casual outsiders" (Owomoyela, 1973). This proverb proves to us that experiences have shown to us that it is best to put up with whatever wrong our relatives and neighbor do to us, as they will be more helpful to us in difficult times than people we only know casually. From past experience, people have believed that it is only your relations who will remain loyal to shoulder your difficulties during the trial period.

In African cosmology and ontology the Africans believe that a child who died can still return to the world as many times as he wishes. Thus, a Yoruba proverb used to buttress this case is: “An Abiku makes the doctor a liar” (Delano, Op.cit). The Yoruba believe that when the mother loses a child in infancy it is the same child who returns and dies. Such a child is known as "Abiku". The above proverb is a metaphysical view of the Yoruba which have been supported in many ways by empirical evidence. "Abiku" is the name given to a child who is destined to die. It is believed that a mischievous spirit (panpsychic animistic spirit) has taken the place of the child in the mother's womb. When the spirit child is about to be born, he promises the other spirits that he will return to the spirit world soon. It is for this reason that children sometimes die young. The spirit has the power to re-enter the same woman several times, if he wishes. An African Panpsyhic animistic seer or native doctor is thought to have no influence on the "Abiku", hence in spite of the treatment given by him, inspite of numerous medicine and injections, inspite of seeming improvement under the doctor's care, the Abiku child will eventually die. The doctor, whose treatments may have seemed very effective, will inevitably be made to appear as a fool or a liar. The proverbs might be used by a person who feels that his own efforts are destined to fail because he has no control over certain situation or, it might be used to explain a failure for which a person does not feel responsible.

\section{Thestic Animistic Communicative Prayer}

Myths are very important elements of theistic Panpsychic animism. They are stones told to explain the origin of things like God, universe, earth, familyhood, rivers, gods, divinities, etc. They are vehicle for Theistic Panpsychic animistic communicative rationality. They are an expression of the unobservable reality in terms of observable phenomena. They are vehicle for conveying certain facts about man's experiences in his supra sensible world. Carl J. Jong's theory of myths is hereby applied to African arts, ontology and cosmology as the psych of humankind and not the Freudian individual psych and on the basis of human instinct but not on Freudian neurosis. In African arts, one could identify a number of basic archetypes and myths speaking for the communal philosophy of the people. However, the following different definition of myths shows 
some concurrence with the supernatural assumptions of African aesthetics and theistic panpsychic rationality:

Myths is fundamental, the dramatic representation of our deepest, institutional life, of a primary awareness of man in the universe, capable of many configurations, upon which all particular opinions and attitudes depend. Myth is to be defined as a complex of stories-some no doubt fact, some fantasy -which, for numerous reasons human beings regard as demonstrators of the inner meaning of the universe and of human life. Myth is the expression of a sense of togetherness-a togetherness not merely on the plane of the intellect, but a togetherness of feeling and of action and of wholeness of living.Myth are by nature, collective and communal; they find a tribe or a nation together in that people's common psychological and spiritual realities (Collier, Op.cit).

A myth endeavors to give explanatory answers to the questions posed to man in this physical universe in which he finds himself. He attempts to probe and answer question about origins and purpose of man on earth. For example, the Ijaw myth of origin of creation says that in the beginning, Tamearau (God) created heaven and earth. Yoruba creation myth says that earth was without form when Olodumare (God) decided to create the earth. He sent orisha-nla, the arch-divinity, to create the solid earth.

These myths raise questions about origin and organization of the universe. The explanation offered by each of them is a theistic one; the world resulted from the activity of a divine being. Also questions like why must man sweat before he eats; why women must labor before they give birth to children, and the like are raised. Answers to questions are naturally clothed in stories, which serve as means of communication and handing them down from generation to generation. These myths give us insight into some of the theistic animistic concepts of the African people who evolved them. With regard to the use of myths as man's communication, they tell us a lot about people's worldview, including their religion. There are some myths, which are creeds, or esoteric ritual formulae, which are sometimes learned and recited like prayers. Myths of this nature enjoy a high degree of authenticity and when properly studied with accurate illustrations, it could provide the basis for a scripture in African religion. Besides, some myths actually explain the dramatic break-through of the sacred into the world. For example, the story or how the world came into being is true because the existence of the world is there to prove it.

Another means of communication is the theistic panpsychic prayer: they pray to God for guidance and blessing in matters of daily life, personal, family or business matters. Africans communicate with God in prayers at anytime in any place. His is their last court of appeal. These prayers are made to God, the deities and the ancestors Ngosian, 1974). Theistic humanistic panpsychic animislic. Prayers are offered for almost everything, from asking for the gift of children, for health, wealth or rain, good harvest to requesting for success in trade, or hunting, most of these prayers are short and to the point through they are also example of long and formal prayers (Ngosian). Praying is recorded among practically all African peoples through the actual prayers have not often been recorded in written form. Few examples would be considered to illustrate the concepts and contents of African prayers in relation to their beliefs and rational communication with God, gods and ancestors. In an animistic manner, it is common to hear an elderly African man during the early morning hours, asking God to let the day dawn well, to pour upon the people his medicine of health and to drive away the evil forces. For instance, Pygmies pray when there is sick- ness and before undertaking a journey or going to hunt, asking God to heal the sick, prosper the traveler and give game to the hunter. Similarly, a hymn of prayer committing the Yoruba worshippers to the care of God says "father of children” prepare medicine for the children the children have no medicine (Ngosian). This implied that worshippers are entirely dependent upon God who is mightier than other animistic forces like ancestors, gods and divinities. Although most of these prayers are addressed directly to God, most of them come in form of invocation asking God to intervene for a particular purpose. For example an African may ask God, give me rain: Help me oh God: God pity me: These invocations are usually what the individual prays spontaneously and unceremoniously on the spur of the moment. They show that people consider God to be ready to respond to their need and not subject to religious formalities, but most of these supplicators go through the gods and goddesses, ancestors and so on.

\section{Theistic Panpsychic Social and Political System}

The theory of functionalism as a methodology was developed by Broniski Malinowski. He says that "all social processes are causally determined” (Malinowski, 1959). What this implies is that before any new thing can be incorporated in the cultural system, it must satisfy some human need to justify its existence. Incidentally, Functionalism is a mode of understanding and communication in African thought, although the analytical scheme or framework in African reality is theistic, panpsychic and animistic. African society is functionally dominated by a set of values held in network by Theistic humanism and Panpsychic animism which sustains objective natural laws. The hierarchy of forces in African philosophy though theistically panphyschic and animist is conceived and understand as theistic functionalism which is generated by natural laws. This animistic ontology is the, functional superstructure of communicative rationality, which is the nature of beings that inhabit the world, the structure of the cosmos as conceived in terms of unity and interactive of all beings or forces. Basically, interactive and communicative African traditional ontological order falls into three broad categories, Spirits and forces, Human beings, Things (Plants and Animals) The interaction of forces, which Placid Temples, describes in his book, Bantu Philosophy, applies to conception of the relationship between the beings in nature. The order listed above is in descending hierarchy according to the relative power of spirits. This means that Beings are differrentiated in African Ontology according to their vital power or their inherent vital rank. At the head is God who is sovereign over the three worlds posited and those beyond. He posses spirit in its absolute form and have absolute control over all beings. After Him come the deities and ancestors: These are the first fathers and founders of the society. God is not as closely involved in human affairs and natural phenomena as the deities and the ancestral spirits. The local deities and ancestral spirits control natural phenomena while God remains as a kind or superintending power to whom final appeal is made in the event of any injustice. The deity in collaboration with the ancestral spirits controls the moral order. The ancestors constitute the most important chain binding men to God. They occupy an exalted rank in the theistic panpsychic animistic ontological order regarded as living dead. This is because they belong to a hierarchy, participating in the divine interactions, and rational communications with all forces including human beings.

The ancestors follow their order of primogeniture. They form 
a chain through the links of which the elders exercise their authority and influence rationally and communicatively on the living generation. Those living on earth ranks, in fact, after the living dead. The living belong in turn to a hierarchy that is also ordered by their own being in accordance with their primogeniture and vital rank, that is superior and master to other forces that lives on the land. The eldest in an African family or clan is by Divine law the panpsychic animistic authority connecting the ancestors and their descendants, because of his ontological status. It is he who bridges the rational communicative gaps among his people and all inferior forces-animal, plants etc.

In African monarchical societies, the king, following this panpsychic animistic conception of authority is the father, and the king of the people. He is the source of all good living; he is as God himself. Any person who is nominated but is not qualified by reason of vital rank and force, cannot be a king or chief among the kingdoms, because he cannot be the rational communicative link binding the living-dead and the living. In theistic panpsychic funtionalism, there is an ontological chatter whereby, after the category of human forces comes the other forces, animals, plants and minerals, but the important point here is that within each of these categories, is found a hierarchy based on vital force or power, rank and primogeniture whose material apparatus is culture. And it is based on this that the concept of authority in African political system can be defined and understood.

The hierarchy of forces as one face of the theistic panpsyduc animistic metaphysics, and social order, authority and leadership as the other face haves the sociological and behavioristic pattern of functional theory of society. There is a sense in which the subjective and objective explanation of communicative action and social order or public sphere is justified by functionalism and structuralism. For Ernest Nagel, "the functional view of culture insists upon the principle that every custom, material object and others fulfill a vital function within a working whole" (Punaman, 1973). Structuralism asks the question of "what are its constituents or what is it made of?” (Norman) and justice in theistic panphyschic animistic society is the constituents of the hierarchical order are God, gods, ancestor, elders, etc. However, structural functionalism is an attempt on a large scale to combine the methods of both functionalism and structuralism which is not only extant in African philosophy but also embedded in the practice of tradition. Indeed Theistic Panpsychic rationality is culturally structural and functional thereby qualifying to be described as structural functional Panpsychic communicative animism.

\section{Conclusion}

Critically speaking the problems of communicative rationality in theistic panphychic animistic philosophy of culture, that is, African philosophy is inherent in the functional-structural nature or epistemological frame work. The limitations border on the dogmatic and unscientific concepts which are replete in the philosophy of culture such as forces, spirits, gods etc. Again the vulnerability of cultural predisposes all the elements of function and structure to disuse and disservices. Yet Culture cannot be rooted out, rather culture may grow, undergo transformation or it may evolve. However the greatest problems to African rational communicative symbols and actions like oral tradition proverbs, myths and prayer is the impart of acculturation.

Contemporary Africa is the result of tremendous ideological and infrastructural changes, all of which have altered the patterns of aesthetic and communicative rationality of Africans, and even the African oral traditions. Access to multiplicity of ideas contributes greatly to the negative and positive definition of rationality form. Access to improved technology made possible the use of foreign production tools and devices, which impact heavily on traditional values. Consequently, there is need to improve and scienticize Theistic Panpsychic animism but not to embrace hollow sciences and the god of materialism.

\section{References}

Aderibigbe, I. (1997). Religion, study and practice (pp. 156-157). Lagos: Almon School Press Ltd.

Adorno, G. A., \& Tiedesmann, R. (1984). Art, society, aesthetics. In C. Lenhardt (Ed.), Aesthetics theory (pp. 21-22). London: Routledge And Kegan Paul.

Ajayi, S. A. (1981). West African traditional religion (p. 2). AdoEkiti: Omolayo Standard Press.

Ajibola, J. O. (1974). Owe Yoruba (p. 60). Ibadan: University Press Ltd. Akinlade, K. (1982). Owe ati humo (p. 20). Ibadan: Abiprint Publishing Company Ltd.

Bernstein, R. J. (ed.) (1985). “Introduction” in Habermas and Modernity (p. 18). Cambridge, Massachusetts: The MIT Press.

Brown, R. (1952). Structure and function as primitive society. (pp. $157-$ 159). London: Cohen and West.

Collier, E. (1986). The African presence in Black American literary criticism. In J. O. Okpaku, A. E. Opubor, B. O. Oloruntimehin (Eds.), The arts and civilization of Black and African people (p. 114). Lagos: Centre for Black and African Arts and Civilization.

Delano, I. O. (1972). Owe Lesin Oro Yoruba proverbs (p. 11). Ibadan: Oxford University Press.

Egonwa, O. D. (1994). African art (p. 14). Edo: Edo State House of Assembly Printing Press.

Gove, P. B. \& Merriam Company G. C. (1971). Webster's third new international dictionary (p. 242). Chicago: William Benton.

Henigo, D. (1982). Oral Histomography. London: Longman.

Jacobs, A. B. (1997). A textbook on African traditional religion (pp. 10-16). Ibadan: Aromolaran Press Ltd.

Malinowski, B. (1959). Crime and causation in savage society (p. 2). Paterson, NJ: Litter Field, Adams.

Martin, F. D., \& Jacobus, L. A. (1983). The humanities through the arts (3rd ed., p. 452). Boston: McGraw-Hill.

Mbiti, J. S. (1996). African religions and philosophy (pp. 85-86). London: Heinemann Pub.

Nigosian, S. A. (1974). World religions (p. 24). London: G Clark Publishing Co. Ltd.

Nomans, G. (1973). Bringing men back in Ryan Alan, the philosophy of social explanation (p. 51). Oxford: Regions.

Odujinrin, J. S. A. (1984). Modern lessons in Yoruba (p. 80). London: Waterloo Press Ltd.

Oladele, T. (1967). An introduction to West African literatures (p. 26). Hong Kong: Thomas Nelson Ltd.

Owomoyela, B. L. O. (1973). Yoruba proverbs (p. 37). Ohio: Owomoyela Press.

Punaman, W. G. (1973). What is structuralism? In R. Alan (Ed.), The philosophy of social explanation (pp. 182-202). Oxford: Regions.

Steva, V. (1996). Social change (p. 84). Saddle River: Prentice Hall, Inc.

Urmson, J. O. (1984). The concise encyclopedia of western philosophy and philosophers. In S. V. (Ed.), Aesthetics (New ed.). 